\title{
РОЛЬ МЕДИЧНОЇ СЕСТРИ НА СУЧАСНОМУ ЕТАПІ РОЗВИТКУ ОХОРОНИ ЗДОРОВ'Я
}

\author{
О. М. Петрущак, І. Я. Криницька \\ Медичний центр Святої Параскеви, м. Львів \\ ДвнЗ «Тернопільський державний медичний університет \\ імені І. Я. Горбачевського МОз Украӥни»
}

У статті викладено сучасні дані щодо професійних якостей медичної сестри у сфері догляду за пацієнтами терапевтичного профілю на сучасному етапі та нових стратегій розвитку сестринської справи.

\section{THE ROLE OF NURSING STAFF IN THE MODERN STAGE OF HEALTH SYSTEM}

\author{
O. M. Petrushchak, I. Ya. Krynytska \\ Medical Center of St. Paraskeva, Lviv \\ I. Horbachevsky Ternopil State Medical University
}

The article presents current data on professional qualities of a nurse in the field of care for patients with a therapeutic profile at the present stage and new strategies for the development of nursing.

Вступ. Глобалізація та інтеграція сучасного суспільства, визнання світовою спільнотою проблеми фізичного, морального і соціального здоров'я як головного показника соціально-економічної зрілості, культури й успішності держави, соціальний запит на якість медичних послуг зумовлюють особливі вимоги до професійної діяльності медичного персоналу. Медична сестра повинна досконало володіти клінічним мисленням, фундаментальними і спеціальними знаннями й уміннями щодо комплексного догляду за пацієнтами, надання медичної допомоги, активного здійснення профілактичної діяльності у сфері охорони здоров'я відповідно до національних і світових професійних стандартів, норм професійної моралі та етики, що відповідає принципу гуманності [1].

Основна частина. Сучасне трактування ВООЗ сестринської справи містить у собі не лише визначення ії місця і завдань у системі охорони здоров'я, а й чітко окреслює коло функціональних обов'язків: «Сестринська справа - це складова частина системи охорони здоров'я, яка направлена на вирішення проблем індивідуального та громадського здоров'я населення в мінливих умовах навколишнього середовища. Сестринська справа включає діяльність зі зміцнення (c) О. М. Петрущак, І. Я. Криницька, 2017 здоров'я, профілактики захворювань, надання психосоціальної допомоги особам, які мають фізичні та (або) психічні захворювання, а також непрацездатним всіх вікових груп» [2].

Стрижнем моделі сестринської справи є сестринський процес, для здійснення якого медична сестра повинна володіти теоретичними основами терапії, практичними вміннями, повинна вміти користуватися медичною технікою, знати основи клінічної фармакології, що сприяє підвищенню професіоналізму і компетентності в практичній діяльності, створенню умов для майбутнього професійного зростання.

Основоположними принципами світової концепції сестринської справи на сучасному етапі можна вважати такі [3]: 1) лікарська і сестринська справа взаємопов'язані, доповнюючі один одного процеси, що становлять дві самостійні професії - лікарська справа (вивчає патологічні процеси, хвороби, що розвиваються на їх фоні, способи впливу на ці патологічні процеси) і сестринська справа (вивчає реакцію індивідуума на хворобу); 2) в основі тієї чи іншої професії повинні лежати загальні фундаментальні знання, а повноцінна фундаментальна діяльність повинна включати три взаємозалежних складових філософію, теорію і практику; 3) сестринська справа 
як молода професія, ґрунтується лише на практиці, поступово освоює нову філософію, розвиваючись як професія. При цьому формується інша психологія медичної сестри, яка виконує роль фахівця - партнера лікаря і пацієнта, здатного до самостійної роботи в рамках єдиної лікувальної бригади і яка в основу своєї професійної діяльності ставить особистість пацієнта. Сестринська справа існує і розвивається як унікальна форма гуманітарної допомоги, ґрунтується на всебічній підтримці з боку суспільства; 4) медична сестра несе юридичну відповідальність за свою професійну діяльність, яка регламентується відповідними правовими актами; 5) в основі сестринської допомоги лежить таке поняття, як сестринський процес, який складається з ряду етапів. Першим етапом сестринського процесу $є$ сестринське обслуговування. Другим етапом сестринського процесу $є$ сестринська діагностика і виявлення проблем пацієнта. При визначенні пріоритетних проблем медсестра повинна спиратися на лікарський діагноз, знати спосіб життя пацієнта, чинники ризику, які погіршують його стан, пам'ятати про емоційний і психологічний стан. Сестринський діагноз - це стан здоров'я пацієнта (теперішній та потенційний), встановлений в результаті проведеного сестринського обстеження і вимагає втручання з боку медичної сестри. Третій етап сестринського процесу - визначення цілей сестринських втручань. Четвертий етап сестринського процесу - планування обсягу сестринських втручань і реалізація плану. Варто пам'ятати, що плануючи догляд за пацієнтом необхідно з'ясувати, якого результату він хоче домогтися. У плані із догляду може бути записано кілька можливих втручань. Це дозволяє медсестрі та пацієнту відчувати впевненість, що для вирішення однієї проблеми можуть бути зроблені різні дії. Незалежні сестринські втручання - це дії, здійснювані медсестрою без прямого призначення лікаря. Вони здійснюються при: наданні допомоги пацієнтові в здійсненні природних потреб; спостереженні за реакцією пацієнта на хворобу, адаптація його до хвороби; спостереженні за реакцією пацієнта на лікування, адаптація його до лікування; навчанні пацієнта (його родичів) самодогляду (догляду); консультуванні пацієнта щодо його здоров'я. П'ятим етапом сестринського процесу $\epsilon$ оцінка результатів і корекція догляду.

На сьогодні в нашій країні постійно проводиться робота щодо забезпечення високої якості сестринського догляду. Змінюються вимоги і ставлення суспільства до сестринської практики, системи про- фесійної сестринської освіти, вдосконалюються сучасні сестринські технології. Так, в Європі та інших країнах медсестра сприймається не тільки як «права рука» лікаря, а й як абсолютно автономний медичний працівник, який в змозі та в праві самостійно приймати рішення стосовно діагностування, лікування, а також відновлення працездатності та реабілітації хворого [2].

В Україні ж проведене чітке розмежування функціональних обов'язків лікарів та медсестер. Сьогодні в лікувально-профілактичних закладах України працює понад 402,8 тисячі молодших спеціалістів із медичною освітою. Із них понад 290 тисяч - медичні сестри, що становить 61,0 \% від усієї кількості молодших спеціалістів з медичною освітою. Співвідношення між лікарями і середніми медпрацівниками становить 1 до 2,15 [5]. Наразі права медсестер не захищені ані на соціально-економічному, ані на законодавчому рівнях. Експерти говорять, що лише декілька дуже потрібних законодавчих актів щодо роботи медичного персоналу існують на папері. Наприклад, проект Закону «Про організацію медичного обслуговування», в якому звертається увага на медичну сестру як повноцінного учасника відносин із надання медичної допомоги між пацієнтами та заходами охорони здоров'я, оскільки цим нормативом передбачається створення закладів сестринського догляду.

Сьогодні ми повинні чітко визначити, яким хочемо бачити медсестринство України вже в найближчі роки і які нагальні кроки для цього необхідно зробити. Головне завдання - визначити на найближчі роки стратегію розвитку сестринської справи, мета якої полягатиме у підвищенні статусу середніх медичних працівників, що сприятиме забезпеченню належного рівня здоров'я українських громадян.

Висновки. В Україні роль медсестринства та престижність цієї професії $\epsilon$ набагато меншою ніж у світі. 3 метою забезпечення реалізації програми розвитку медсестринства на наступні роки та покращення роботи медсестринської служби, підвищення ролі медсестер у системі охорони здоров'я і розвитку лідерства у медсестринстві необхідно забезпечити: 1) удосконалення організації роботи та кадрової політики в розвитку медсестринства; 2) удосконалення професійної освіти; 3) нормативно-правове забезпечення діяльності медичних сестер; 4) інформаційне забезпечення в управлінні діяльністю медичних сестер; 5) розвиток професійних сестринських об'єднань, асоціацій та співробітництва у медсестринстві. 


\section{СПИСОК ЛІТЕРАТУРИ}

1. Баршай Т. И. Образ идеальной медицинской сестры у выпускников медучилища и медсестер [Электронный ресурс] / Т. И. Баршай. - Режим доступа : http://media. miu. by/files/store/items/uses/xvii/mim uses xvii 34QQ4.pdf.

2. Безкоровайна У. Ю. Порівняльний аналіз ролі медичної сестри в Україні та у світі / У. Ю. Безкоровайна // Інвестиції: практика та досвід. - 2016. - № 15. - С. 88-91.

3. Веткина О. А. Пути оптимизации деятельности среднего медицинского персонала отделений лучевой диагностики в современных условиях : дисс. ... канд. мед. наук / О. А. Веткина. - СПб., 2009. - 171 с.

4. Лычев В. Г. Сестринское дело в терапии с курсом первичной медицинской помощи / В. Г. Лычев, Т. Т. Карманова.- М. : Форум-Инфра, 2009.

5. Міністерство охорони здоров'я України [Електронний ресурс]. - Режим доступу : http://www.moz.gov.ua/ ua/portal/

Отримано 31.10.17 